\title{
The Ethical Challenge of Digital Bioarchaeological Data
}

Brenna R. Hassett, Institute of Archaeology, University College London, 31-34 Gordon Square, London, WC1H OPY, UK

E-mail: b.hassett@ucl.ac.uk

\section{ABSTRACT}

Introduction to the Special Issue: Digital Bioarchaeology: New Dimensions, New Methods, New Ethics.

Résumé: Présentation du numéro spécial: Bioarchéologie numérique: nouvelles dimensions, nouvelles méthodes, nouvelles éthiques.

Resumen: Introducción al número especial: Bioarqueología digital: nuevas dimensiones, nuevos métodos, nueva ética.

\section{KEY WORDS}

Ethics, Bioarchaeology

\section{The Ethical Dilemma}

Like most fields of scientific enquiry, the discipline of bioarchaeology has been affected by the proliferation of digitally accessible forms of information. What makes digital bioarchaeological data unique among the archaeological sciences grappling with these issues is that bioarchaeology includes the study, in varying forms and methods, of human remains. Human remains pose particular ethical challenges for researchers and curators. The subject is emotive for many, which is it not itself unrelated to the imperialist, racist, misogynist, and other discriminatory approaches that were embedded in the historical development of both physical anthropology and archaeology. Many human remains were 'collected' over the last two centuries to establish a physical proof for theories of racial differences (Fforde 2013); with the study of human remains, like the study of humanity itself, 
rooted in the colonialism and imperialism of 18th and 19th century Western thought (Alfonso and Powell 2007). In the modern day, the disposition of human bodies remains inextricably linked to structures of power, as can be seen in the destruction and desecration of burial places in contested territory (Stutz 2013) and the ongoing contests between state and national level actors and descendent communities for control over indigenous remains in or originating from former colonial territories (Turnbull and Pickering 2010). Philip Walker evocatively described the dilemma bioarchaeologists and museums holding bioarchaeological research collections face:

[W] hat are the ethical responsibilities of skeletal biologists? On one hand, we have bioarchaeologists who believe that the historical evidence obtained from human remains is critical for defending humankind against the historical revisionist tendencies of repressive, genocidal political systems, and, on the other, we have indigenous people who believe that the spirits of their ancestors are being tortured on the shelves of museums by racist, genocidal, colonial oppressors (Walker 2000, p. 18).

It is unsurprising then that data and research derived from these collections should generate similar levels of controversy. However, what has not been considered in as great detail are the new ethical challenges posed by an entirely new way of 'holding' human remains as digital objects.

This volume brings together papers from a wide array of disciplinary perspectives, including physical anthropology, archaeology, museums, and forensics. Papers survey the potential benefits of digital bioarchaeological data, discuss the importance of standardisation in both capturing and reproducing suitable digital bioarchaeological data, take stock of current practice, and above all concern themselves with the ethical implications of what has become an integral part of modern practice.

\section{Challenges: Ethics and Access}

The increase in new methods of collecting specimen data, channels and in means to convey these, especially as images or $3 \mathrm{~d}$ shapes, and the potential for disseminating these must be subject to the same kind of ethical consideration that any work with human remains requires. There is currently no set standard for best practice in creating, curating, or disseminating digital bioarchaeological data. In fact, digital heritage at large faces similar issues. The stated goal for all elements of digital heritage, under the UNESCO Charter of 2003, is of increasing access to digital collections (UNESCO 2003). Ethical considerations have been largely confined to issues like re- 
usage rights and appropriate use of metadata (Manžuch 2017). However, these polices must be adapted in light of the special nature of human remains, as acknowledged in the Tamaki Makau-rau Accord:

[T] he display of human remains and sacred objects is recognised as a sensitive issue. Human remains include any organic remains and associated material. [...] Display means the presentation in any media or form of human remains and sacred objects, whether on a single occasion or on an ongoing basis, including conference presentations or publications. Tamaki Makau-rau Accord on the Display of Human Remains and Sacred Objects, adopted WAC 2006 Osaka (World Archaeological Congress 2006)

Recently, important work has been done to bring the issue to the forefront of disciplinary attention (see the papers in Thompson and Errickson 2017), but we must continue to interrogate the processes by which digital bioarchaeological data are collected, standardised, attributed, and disseminated as the technology for doing so changes. It is my hope that these papers, particularly the open discussion from different disciplinary perspectives transcribed in the final paper, and the text of resolution on digital bioarchaeological ethics adopted by the World Archaeological Congress, will form an important part of what should always be an ongoing, evolving dialogue on the ethics of our research.

\section{Compliance with Ethical Standards}

Conflict of interest statement There is no conflict of interest.

\section{References}

Alfonso, M. P., \& Powell, L.

(2007). Ethics of flesh and bone, or ethics in the practice of paleopathology, osteology and bioarchaeology. In N. O. Vicki Cassman \& J. Powell (Eds.), Human remains: Guide for museums and academic institutions. Lanham: Alta Mira Press.

Fforde, C.

(2013). In search of others. In L. N. Stutz \& S. Tarlow (Eds.), The oxford handbook of the archaeology of death and burial. Oxford: Oxford University Press.

Manžuch, Z.

(2017). Ethical issues in digitization of cultural heritage. Journal of Contemporary Archival Studies, 4, 1-17. 
Stutz, L. N.

(2013). Contested burials. In L. N. Stutz \& S. Tarlow (Eds.), The oxford handbook of the archaeology of death and burial. Oxford: Oxford University Press.

Thompson, T., \& Errickson, D. (Eds.).

(2017). Human remains: Another dimension. The application of imaging to the study of human remains. London: Academic Press.

Turnbull, P., \& Pickering, M. (Eds.).

(2010). The long way home: The meaning and values of repatriation. Oxford: Berghahn Books.

UNESCO Charter on the Preservation of Digital Heritage. UNESCO: UNESCO (2003).

Walker, P. L.

(2000). Bioarchaeological ethics: A historical perspective on the value of human remains. In M. A. Katzenberg \& S. R. Saunders (Eds.), Biological anthropology of the human skeleton (pp. 3-39). Hoboken: Wiley-Liss.

World Archaeological Congress.

(2006). Tamaki Makaurau accord on the display of human remains and sacred objects. Osaka: World Archaeological Congress Inter-congress. 